\title{
Maharah al-Qira'ah Learning Model through Edmodo at Department of Arabic Language Education, Imam Bonjol State Islamic University, Padang
}

\author{
Neli Putri \\ Universitas Islam Negeri (UIN) Imam Bonjol Padang \\ neliputri@uinib.ac.id \\ Rahmawati \\ Universitas Islam Negeri (UIN) Imam Bonjol Padang \\ rahmawati@uinib.ac.id \\ Hanomi \\ Universitas Islam Negeri (UIN) Imam Bonjol Padang \\ hanomisyam@gmail.com
}

\begin{abstract}
This study aims to determine the validity of Maharatul Qira'ah learning model design by utilizing Edmodo e-learning application, and to describe the learning model and its impact on student participation. The rapid development of ICT is influencing the Arabic learning model at PBA UIN IB Padang which is still using the classical model, and the participation of students is still lacking. Here, the innovation of the classical learning model toward online-based learning needs to be done, such as by utilizing Edmodo e-learning application. This research used the ADDIE step model. The research subjects consisted of 32 students and 5 lecturers of PBA. This study used valid instruments. Based on the data analysis, the validity of the design of the teaching materials presented in the Edmodo e-learning has met the very valid criteria, with a score of 83.59. The e-learning model developed was a blended learning with complement functions in the form of synchronous and asynchronous communication. This elearning had been able to increase student participation by $81,25 \%$. This study recommends further researchers to use Edmodo e-learning application in teaching various language skills in a fully integrated online model.
\end{abstract}

Keywords: Learning model; maharatul qira'ab; edmodo 


\begin{abstract}
Abstrak
Penelitian ini bertujuan untuk mengetahui validitas desain model pembelajaran maharatul qira'ah dengan e-learning Edmodo dan menggambarkan model pembelajarannya serta dampaknya pada tingkat partisipasi mahasiswa. Perkembanga ICT yang semakin pesat telah memberi pengaruh terhadap model pembelajaran bahasa Arab di PBA UIN IB Padang yang masih bersifat klasikal dan partisipasi mahasiswa masih kurang. Inovasi model pembelajaran ke arah pembelajaran berbasis online perlu dilakukan, seperti dengan menggunakan aplikasi e-learning Edmodo. Penelitian pengembangan ini menggunakan langkah model ADDIE. Subjek penelitian terdiri dari 32 orang mahasiswa, 5 orang dosen PBA. Instrumen yang digunakan adalah instrumen validitas. Berdasarkan perolehan score analisis data validitas desain materi ajar yang akan disajikan pada e-learning Edmodo telah memenuhi kriteria sangat valid yaitu dengan score 83,59. Model $e$ learning yang dikembangkan adalah blended learning dengan fungsi complement dalam bentuk komunikasi syncronous dan asyncronous. Edmodo ini telah dapat meningkatkan partisipasi mahasiswa sebesar $81,25 \%$. Penelitian ini merekomendasikan penelitian lanjutan untuk menggunakan Edmodo pada keterampilan bahasa lain dengan model fully online.
\end{abstract}

Kata Kunci: Model pembelajaran, mabaratul qira'ah, edmodo

\title{
Introduction
}

The concept of e-learning is a logical consequence of the rapid development of information and communication technology. The presence of this media can facilitate, assist the learning process, and improve learning outcomes. ${ }^{1}$ E-learning is a solution when there is an imbalance in the number of students compared to the number of teaching staff and facilities available, as well as the limitations of students not being able to physically attend each lecture. The demand for skills in the 21 st century technology and communication literacy (literacy) has become an important basic skill after reading, writing, and arithmetic. ${ }^{2}$ Innovations in learning technology must receive support from various parties ${ }^{3}$, such as the government, especially from

${ }^{1}$ Greg Kessler, “Technology and the Future of Language Teaching," Foreign Language Annals 51, no. 1 (2018): 205-18, https://doi.org/10.1111/flan.12318.

2 Parlindungan Pardede, "Integrating the 4Cs into EFL Integrated Skills Learning" 6, no. March (2020): 71-85, https://doi.org/10.33541/jet.v6i1.190.

${ }^{3}$ Suci Ramadhanti Febriani et al., "Arabic Learning for Elementary School During COVID-19 Emergency in Indonesia," OKARA 14, no. 1 (2020): 67-80, https://doi.org/10.19105/ojbs.v14i1.3194. 
the Directorate General of Higher Education, Ministry of National Education. The Directorate must stimulate universities in Indonesia to build a web-based learning system.

Students live in a constantly changing space and time, so educators must be able to recognize themselves in the demands of current and future global developments. ${ }^{4}$ Technological competence, pedagogy, and learning content to be taught are all required of educators in the twenty-first century, also known as Technological, Pedagogical, and Content Knowledge (TPACK). ${ }^{5}$ IT must be used in the implementation of Arabic language learning in universities. To be able to teach students effectively, technology must be used correctly and appropriately. ${ }^{6}$ Many people's perceptions of web-based learning have begun to shift as a result of the availability of forum and chat features in e-learning media. ${ }^{7}$ Even if they do not meet physically, existing multimedia and the increasingly rapid development of the web world can help realize interactive learning. ${ }^{8}$ According to a study, using technology in education, including social media, can boost students' creativity and learning motivation. ${ }^{9}$ Social media also allows students to explore a wide range of materials in a time-efficient manner. ${ }^{10}$ It is critical to use information and communication technology as a tool in the teaching and learning of a foreign language. ${ }^{11}$ Based on the successes of electronic-based learning implementation, the learning process can be carried out in an integrated manner, including the presence of materials, strategies, and

${ }^{4}$ Janniarni Toha Safutri, Suci Ramadhanti Febriani, and Danial Hilmi, "Improvement Of Arabic Language Tearcher Competency Based On Multiple Intelligences," Lughawiyyah 2, no. 1 (2020).

${ }^{5}$ Dorit Maor, "Using TPACK to Develop Digital Pedagogues: A Higher Education Experience," Journal of Computers in Education 4, no. 1 (2017): 71-86, https://doi.org/10.1007/s40692-016-0055-4.

${ }^{6}$ Noor Mohd Ariff Brahin et al., "Development of Vocabulary Learning Application by Using Machine Learning Technique," Bulletin of Electrical Engineering and Informatics 9, no. 1 (2020): 362-69, https://doi.org/10.11591/eei.v9i1.1616.

7 Nahla Aljojo et al., "The Design and Implementation of an Arabic Pronunciation Application for Early Childhood," Journal of Technology and Science Education 9, no. 2 (2019): 13652, https://doi.org/10.3926/jotse.486.

8 Vít Dočekal and Hana Tulinská, "The Impact of Technology on Education Theory,"

Procedia - Social and Behavioral Sciences 174 (2015): 3765-71, https://doi.org/10.1016/j.sbspro.2015.01.1111.

${ }^{9}$ Suci Ramadhanti Febriani and Anasruddin Anasruddin, "Technology for Four Skills Arabic in the Era Emergency of Covid-19 in Indonesia," Ta'lim Al-'Arabiyyah: Jurnal Pendidikan Bahasa Arab \& Kebahasaaraban 4, no. 1 (2020): 1-11, https://doi.org/10.15575/jpba.v4i1.8221.

${ }^{10}$ Inda Nofrika, "EFL Students' Voices: The Role of YouTube in Developing English Competences," Journal of Foreign Languange Teaching and Learning 4, no. 1 (2019), https://doi.org/10.18196/ftl.4138.

${ }^{11}$ Raniah Kabooha and Tariq Elyas, "The Effects of YouTube in Multimedia Instruction for Vocabulary Learning: Perceptions of EFL Students and Teachers," English Language Teaching 11, no. 2 (2018): 72, https://doi.org/10.5539/elt.v11n2p72. 
an electronic-based evaluation system. This facilitates the teaching and learning process for both educators and students. ${ }^{12}$ The e-learning system also allows students to be creative and think critically about their online interactions. ${ }^{13}$ Furthermore, its application in Arabic learning, such as maharatul qira'ah, can provide opportunities for students to find various online learning references ${ }^{14}$ and find materials contextually based on their needs.

Arabic learning has been going on for a long time at UIN Imam Bonjol Padang, but the use of IT in learning is still limited and incomplete. Lectures are still delivered in a traditional manner, and student activities are limited. Learning innovation is required in order to deliver educational and teaching programs that are progressive and relevant to the times. Arabic language learning must be based on e-learning in this digital and technological era. During the learning process, online lectures can increase motivation, interest, and activity. Learning Arabic using the TPACK framework is in high demand these days. Learning is expected to be effective, efficient, diverse, and enjoyable. The facts show that students and lecturers are already familiar with the use of communication technology media such as social media including FB, WA, Twitter, Instagram, and other applications ${ }^{15}$. PBA UIN IB students and lecturers in general are accustomed to incorporating IT into lectures and utilizing it as a means of communication. This condition is not an impediment if the lecture is delivered via e-learning. The use of IT-based learning media must be in accordance with the learning/lecture needs. ${ }^{16}$ The Edmodo application is one type of e-learning that can be used to learn Arabic. This application is a social component, similar to Facebook. It is a personal social media platform for both lecturers and students containing educational content. Edmodo facilitates the development of an online learning process. ${ }^{17}$ An educator/lecturer will be able to more easily

12 Chiu Lan Chang and Ming Fang, "E-Learning and Online Instructions of Higher Education during the 2019 Novel Coronavirus Diseases (COVID-19) Epidemic," Journal of Physics: Conference Series 1574, no. 1 (2020): 0-5, https://doi.org/10.1088/17426596/1574/1/012166.

13 Erika E. Smith, "Social Media in Undergraduate Learning: Categories and Characteristics," International Journal of Educational Technology in Higher Education 14, no. 1 (2017), https://doi.org/10.1186/s41239-017-0049-y.

${ }^{14}$ Afendi Hamat and Haslinda Abu Hassan, "Use of Social Media for Informal Language Learning by Malaysian University Students," 3L: Language, Linguistics, Literature 25, no. 4 (2019): 68-83, https://doi.org/10.17576/3L-2019-2504-05.

${ }^{15}$ Mohammeed A. AlGhamdi, “Arabic Learners' Preferences for Instagram English Lessons," English Language Teaching 11, no. 8 (2018): 103, https://doi.org/10.5539/elt.v11n8p103.

${ }^{16}$ Wildana Wargadinata et al., "Mediated Arabic Language Learning for Arabic Students of Higher Education in COVID-19 Situation," Izdihar: Journal of Arabic Language Teaching, Linguistics, and Literature 3, no. 1 (2020): 59-78, https://doi.org/10.22219/jiz.v3i1.11862.

${ }^{17}$ Yau Wai Lam, Khe Foon Hew, and Kin Fung Chiu, "Improving Argumentative Writing: Effects of a Blended Learning Approach and Gamification," Language Learning and Technology 22, no. 1 (2018): 97-118. 
monitor interactions with students using this platform (in the Edmodo learning environment).

Edmodo was created and designed to pique students' interest in learning in a more intimate setting. Edmodo's goal is to provide a virtual learning environment for teachers and students to bond. The virtual space serves as a classroom or forum for presentation, discussion, discovery, analysis, and evaluation, as well as follow-up activities such as assigning homework and quizzes. Teachers can easily manage a system that offers the best and most practical features for reducing students' anxiety, embarrassment, and fear. This Edmodo application serves two purposes: it facilitates communication during the learning process, and it allows educators to easily track the progress of each student participant in the room. Edmodo offers four registration options for teachers, students, parents, and schools, as well as areas to connect schools to Edmodo.

The literature review also explains that Edmodo provides an environment in which teaching and learning can excite students and make them more self-sufficient, while keeping the standard for measuring learning success in mind. ${ }^{18}$ This Edmodo application can also increase students' motivation to learn. ${ }^{19}$ Technology-based learning also allows students to learn independently ${ }^{20}$ and is in charge of managing their learning activities with a guaranteed security system.

Based on the literacy study on the positive side of Edmodo application, the researchers determined that Arabic language lectures in the PBA study program could be completed online using Edmodo e-learning. Furthermore, the facts show that Arabic learning has not been based on e-learning thus far, and the level of activity is still low. The evolution of lectures toward online-based learning adds a new dimension. This is an attempt to boost creativity and innovation in Arabic lectures, particularly in the PBA UIN IB Padang study program. Researchers are interested in developing mahatul qira'ah learning through the use of Edmodo application, with the following problem formulations:

18 Basori, "Pemanfaatan Social Learning Network "Edmodo" Dalam Membantu Perkuliahan Teori Bodi Otomotif Di Prodi PTM JPTK FKIP UNS," JIPTEK 6, no. 2 (2013): 99.

${ }^{19}$ Halaleh Ma'azi and Kamran Janfeshan, "The Effect of Edmodo Social Learning Network on Iranian EFL Learners Writing Skill," Cogent Education 5, no. 1 (2018): 1-17, https://doi.org/10.1080/2331186X.2018.1536312.

${ }^{20}$ Olivia Halic et al., "To Blog or Not to Blog: Student Perceptions of Blog Effectiveness for Learning in a College-Level Course," Internet and Higher Education 13, no. 4 (2010): 206-13, https://doi.org/10.1016/j.iheduc.2010.04.001. 
1. How is the validity of the Maharatul qira'ah learning design with Edmodo elearning viewed from the learning objectives, material content, assignments, quizzes and evaluations?

2. How is the description of the Maharatul qira'ah learning model with Edmodo at PBA UIN IB Padang and its impact on the level of student participation during learning?

This study is expected to be beneficial to all aspects of learning, including lecturers, students, study programs, faculties, and universities.

This is a development study that employs the ADDIE model, which includes analysis, design, development or production, implementation or delivery, and evaluations. The stages of development research carried out are analysis, design, development, and implementation. Due to limitations in ability, time, and energy, the researcher conducted a trial only to assess the level of students' participation in lectures using the effectiveness instrument. The development research procedure is outlined below.

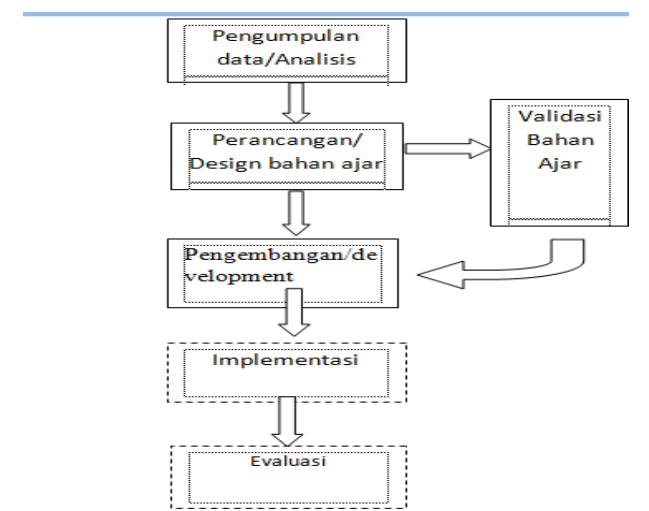

\section{Figure 1. The Procedure of Developing ADDIE}

According to Figure 1, the data of this research were both qualitative and quantitative. Qualitative data were gathered by means of interview and documentation techniques. While, the quantitative data were obtained from the validation sheet, the questionnaires filled in by student and lecturer respondents. The data sources included 5 PBA study program lecturers and 32 PBA study program students. The data were processed and analyzed using interpretive descriptive methods. The research objective was referred to as the research instrument. The instrument used referred to the instrument of teaching material validity. The purpose of validating this material was to determine its suitability based on educational criteria such as curriculum (objectives), content, and language. The qualitative data were analyzed descriptively, namely by describing the needs analysis results and the validities of the objectives, teaching materials for learning maharatul qira'ah, and the language used. The goal of the questionnaire data analysis for need assessment was to convert the qualitative 
value (Likert scale) to a quantitative value. The validity data analysis (instrument) converted a qualitative value (Likert scale) to a quantitative value.

\section{Results and Discussion}

Stage of analysis. The analysis was carried out to determine the field conditions related to the already running Maharatul Qira'ab lectures and to gain an overview of the needs for the development of learning models. The analysis was carried out by distributing questionnaires and conducting interviews. To determine the instrument's feasibility, the questionnaire to be distributed was validated and tested for its reliability first. The questionnaire results indicated the following:

1. Lecture Process: (a) the lecture system (93.3\%) is still traditional (classical), (b) Student involvement $(71.87 \%)$ is still lacking/low, and (c) student interaction with lecturers $(68.3 \%)$ is still lacking/low or still insufficient.

2. The impact of the previously run PBA model: (a) Lecture activities $(68.3 \%)$ have aided students in mastering the materials. (b) Lecture model (68.74\%) has increased student participation in lectures (ask, answer, express opinions/ideas), (c) lecture model (53.13\%) has grown courage in expressing their opinions/ideas.

3. The need for lecture innovation: (a) $98.97 \%$ of respondents stated that the lectures held thus far require innovation, (b) $87.5 \%$ of BA lectures require technology; (c) $87.5 \%$ of Arabic learning models must be developed from traditional to online learning models.

4. IT readiness: (a) $84.37 \%$ of the available facilities allow for the implementation of electronic-based Arabic lectures (e-learning), (b) 99.99\% of students enjoy lectures if using/utilizing technology, and (c) 90.62\% of respondents have a high proclivity to implement e-learning-based lectures.

The results of the development needs analysis interview also showed that: a) the lecture model used was traditional and monotonous, with face-toface, presentation systems, discussions, and few assignments. In comparison to other universities, the lecture model was less up-to-date compared to other universities. The uses of innovative, creative, and enjoyable models were still limited. b) Student reactions varied during the lecture process; some were serious, enthusiastic, and active in attending lectures, while others were mediocre, less serious, less creative, and appeared bored. c) The impact of the ongoing lecture model: (1) fostering moderate student learning motivation, (2) lack of active participation, (2) lack of courage in asking questions, expressing opinions, and responding to materials, (3) inability to grow and improve selfconfidence, and (4) creativity was dominated by the same people. d) Actions taken to address deficiencies included varying alternative learning models, utilizing technology-based media, and requiring an assessment system with a portfolio. e) Online lecture models must be developed in order to increase the 
creativity and effectiveness of lectures. f) Facilities and resources to support the implementation of online lectures; students had been interested and technologically literate. The existence of curriculum demands, namely the attainment of qualifications was capable of applying the field of expertise and utilizing science and technology in their field in solving problems and adapting to the situation at hand. The Learning Media, Electronic-Based PBA Model, and Electronic-Based PBA Design courses all contributed to this curriculum achievement. Based on the findings of this analysis phase, an e-learning model for maharatul qira'ah lectures must be developed.

Stage of design. The stages of developing the Arabic language learning model (maharatul qira'ab) based on e-learning were the same as the stages of designing learning activities, and they were as follows: a) Formulation of learning outcomes, in accordance with learning outcomes in the KKNI curriculum for PBA study programs, namely: students are able to master the theory of Nizham Lughah 'Arabiyyah in reading Arabic text well, and able to master the concept of word function. b) Intensely developing teaching materials consisted of simple and complex texts related to religion, education, social arts, and culture. The content included conformity with learning outcomes and clear presentation in the application, the content was in accordance with the student's tsaqafah, and the content was organized sequentially. c) Development of evaluation tools was comprised of material expert validation instruments from PBA study program lecturers related to objectives, content, and language.

This development design was validated first by material and media experts. The validation analysis yielded the following results: 1) the learning objectives of maharatul qira'ah received a very valid qualification with a score of $93.3,2)$ the material content received a score of 75.5 with a valid qualification, and 3) assessments in the form of tasks and quizzes which were presented received the score of 92 with very a valid qualification. The overall design validation result was $83.59 \%$, with a very valid qualification (Riduwan modification categorization).

The Development Phase consisted of product design realization activities such as: a) writing teaching material scripts, assignments, and quizzes to be presented on the Edmodo application. b) Registering for an account on the Edmodo e-learning site by going to www.edmodo.com. c) Form subject groups, upload materials, assignments, and quizzes to the Edmodo application, and invite students to the group by first providing the lecturer's Edmodo pin number.

Lectures were created using a blended learning model, which combined face-to-face and online lecture characteristics with Edmodo. The reason for this was that achieving the objectives of the Maharatul Qira'ab lectures required faceto-face contact, such as reading fluently and correcting immediate errors. This 
online lecture served as a supplement to face-to-face lectures. In this e-learning learning, the form of communication used was synchronous in discussion activities and asynchronous in working on assignments and quizzes. Take a look at the recovery design drawings below:

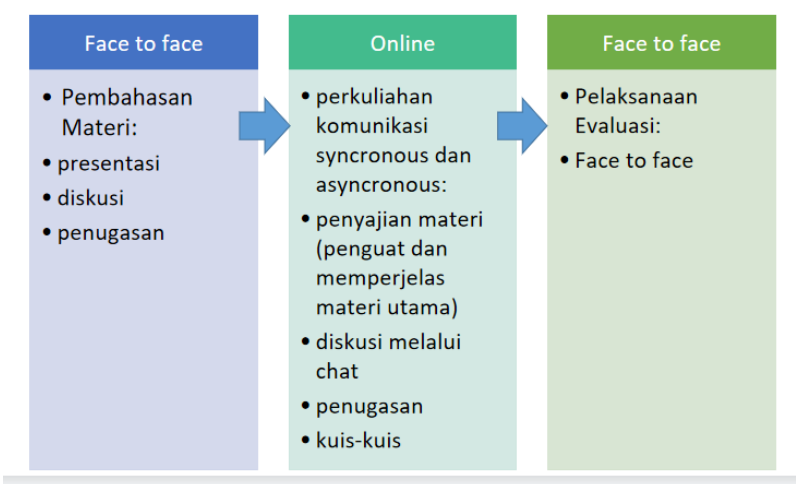

\section{Figure 2. Model of Maharatul Qira'ah Learning Design by Using Edmodo}

Furthermore, the validator validated the manuscripts of teaching materials, assignments, and quizzes (which are to be presented through the Edmodo application), and the total result was 83.59. This acquisition value combined with a very valid qualification indicated that the Mabaratul Qira'ab course material was usable. This study has several limitations, including: 1) The e-learning teaching materials are only designed for six meetings (37.5 percent of the 16 face-to-face). E-learning can be used in place of face-to-face instruction (complement). 2) The research is only in the analysis, design, and development stages, with limited implementation to see indicators of student participation levels. 3) Media expert validation, particularly e-learning via Edmodo, has not been fully implemented and will be continued in the next study. This application can only be used by the user and cannot be modified.

The implementation phase was a trial period for using the maharatul qira'ah learning model with Edmodo. The experiment was carried out in a single local lecture. The researchers observed the Edmodo class and then used validated instruments to analyze the level of student participation during lectures. The student participation rate in Edmodo's classroom was known to be $81.25 \%$ with a high qualification. The evaluation stage followed, with an assessment of the outcomes of the Maharatul Qira'ah learning implementation with Edmodo. E-learning has been shown to increase student participation while studying in the Edmodo room, though this is not a large increase and needs to be increased further to see other benefits.

The image below depicts a description of the e-learning process in maharatul qira'ah lectures using Edmodo. 


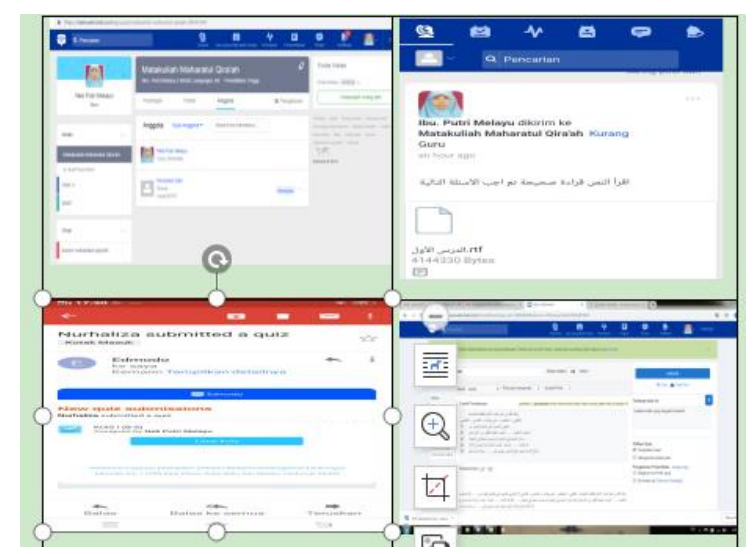

Figure 3. The Process of Learning by Using Edmodo

\section{Conclusion}

Based on the results of the needs analysis stage, it is clear that development is required for learning Arabic, specifically by innovating electronic-based Arabic learning models such as Edmodo. The valid criteria have been met in the design of the teaching materials that will be presented in elearning. The presented e-learning model is blended learning, which serves as a supplement. The development includes the design of the maharatul qira'ah course concept, which includes course objectives, teaching materials, assignments / quizzes, and evaluations. The impact of e-learning on learning has been to increase the participation of students with advanced degrees. This research is completely flawed and requires further refinement so that lectures can be more effective in all aspects. This research has the potential to be expanded. A good internet network facility on campus is required for the smooth implementation of lectures with e-learning. The use of Edmodo in Arabic lectures in general, with a fully online model, is recommended in this study.

\section{Bibliography}

Al-Ghamdi, Mohammeed A. "Arabic Learners' Preferences for Instagram English Lessons." English Language Teaching 11, no. 8 (2018): 103. https://doi.org/10.5539/elt.v11n8p103.

Aljojo, Nahla, Asmaa Munshi, Wafa Almukadi, Azida Zainol, Ihdaa Alanaya, Hawazin Albalawi, Ghadeer Alharbi, et al. "The Design and Implementation of an Arabic Pronunciation Application for Early Childhood." Journal of Technology and Science Education 9, no. 2 (2019): 13652. https://doi.org/10.3926/jotse.486.

Basori. "Pemanfaatan Social Learning Network "Edmodo" Dalam Membantu Perkuliahan Teori Bodi Otomotif Di Prodi PTM JPTK FKIP UNS." 
JIPTEK 6, no. 2 (2013): 99.

Brahin, Noor Mohd Ariff, Haslinah Mohd Nasir, Aiman Zakwan Jidin, Mohd Faizal Zulkifli, and Tole Sutikno. "Development of Vocabulary Learning Application by Using Machine Learning Technique." Bulletin of Electrical Engineering and Informatics 9, no. 1 (2020): 362-69. https://doi.org/10.11591/eei.v9i1.1616.

Chang, Chiu Lan, and Ming Fang. "E-Learning and Online Instructions of Higher Education during the 2019 Novel Coronavirus Diseases (COVID19) Epidemic." Journal of Physics: Conference Series 1574, no. 1 (2020): 0-5. https://doi.org/10.1088/1742-6596/1574/1/012166.

Dočekal, Vít, and Hana Tulinská. "The Impact of Technology on Education Theory." Procedia - Social and Behavioral Sciences 174 (2015): 3765-71. https://doi.org/10.1016/j.sbspro.2015.01.1111.

Febriani, Suci Ramadhanti, and Anasruddin Anasruddin. "Technology for Four Skills Arabic in the Era Emergency of Covid-19 in Indonesia." Ta'lim Al'Arabiyyah: Jurnal Pendidikan Bahasa Arab \& Kebahasaaraban 4, no. 1 (2020): 1-11. https://doi.org/10.15575/jpba.v4i1.8221.

Febriani, Suci Ramadhanti, Rizka Widayanti, Muhammad Afif Amrullah, and Nuril Mufidah. "Arabic Learning for Elementary School During COVID19 Emergency in Indonesia." OKARA 14, no. 1 (2020): 67-80. https://doi.org/10.19105/ojbs.v14i1.3194.

Halic, Olivia, Debra Lee, Trena Paulus, and Marsha Spence. “To Blog or Not to Blog: Student Perceptions of Blog Effectiveness for Learning in a CollegeLevel Course." Internet and Higher Education 13, no. 4 (2010): 206-13. https://doi.org/10.1016/j.iheduc.2010.04.001.

Hamat, Afendi, and Haslinda Abu Hassan. "Use of Social Media for Informal Language Learning by Malaysian University Students." 3L: Language, Linguistics, Literature 25, no. 4 (2019): 68-83. https://doi.org/10.17576/3L2019-2504-05.

Kabooha, Raniah, and Tariq Elyas. "The Effects of YouTube in Multimedia Instruction for Vocabulary Learning: Perceptions of EFL Students and Teachers." English Language Teaching 11, no. 2 (2018): 72. https://doi.org/10.5539/elt.v11n2p72.

Kessler, Greg. "Technology and the Future of Language Teaching." Foreign Language Annals 51, no. 1 (2018): 205-18. https://doi.org/10.1111/flan.12318.

K1lıçkaya, Ferit. "Learners' Perceptions of Collaborative Digital Graphic Writing Based on Semantic Mapping." Computer Assisted Language Learning 33, no. 1-2 (2020): 58-84. https://doi.org/10.1080/09588221.2018.1544912. 
Lam, Yau Wai, Khe Foon Hew, and Kin Fung Chiu. "Improving Argumentative Writing: Effects of a Blended Learning Approach and Gamification." Language Learning and Technology 22, no. 1 (2018): 97-118.

Ma'azi, Halaleh, and Kamran Janfeshan. "The Effect of Edmodo Social Learning Network on Iranian EFL Learners Writing Skill.” Cogent Education 5, no. 1 (2018): 1-17. https://doi.org/10.1080/2331186X.2018.1536312.

Maor, Dorit. "Using TPACK to Develop Digital Pedagogues: A Higher Education Experience." Journal of Computers in Education 4, no. 1 (2017): 7186. https://doi.org/10.1007/s40692-016-0055-4.

Nofrika, Inda. 'EFL Students' Voices: The Role of YouTube in Developing English Competences." Journal of Foreign Languange Teaching and Learning 4, no. 1 (2019). https://doi.org/10.18196/ftl.4138.

Pardede, Parlindungan. "Integrating the 4Cs into EFL Integrated Skills Learning" 6, no. March (2020): 71-85. https://doi.org/10.33541/jet.v6i1.190.

Safutri, Janniarni Toha, Suci Ramadhanti Febriani, and Danial Hilmi. "Improvement Of Arabic Language Tearcher Competency Based On Multiple Intelligences." Lughawiyyah 2, no. 1 (2020).

Smith, Erika E. "Social Media in Undergraduate Learning: Categories and Characteristics." International Journal of Educational Technology in Higher Education 14, no. 1 (2017). https://doi.org/10.1186/s41239-017-0049-y.

Wargadinata, Wildana, Iffat Maimunah, Suci Ramadhanti Febriani, and Luluk Humaira. "Mediated Arabic Language Learning for Arabic Students of Higher Education in COVID-19 Situation." Izdibar: Journal of Arabic Language Teaching, Linguistics, and Literature 3, no. 1 (2020): 59-78. https://doi.org/10.22219/jiz.v3i1.11862.

(https://drappedia.blogspot.com.2018/04, diakses 13 oktober 2018)

(https://www.Edmodo.com) diakses Oktober 2018 